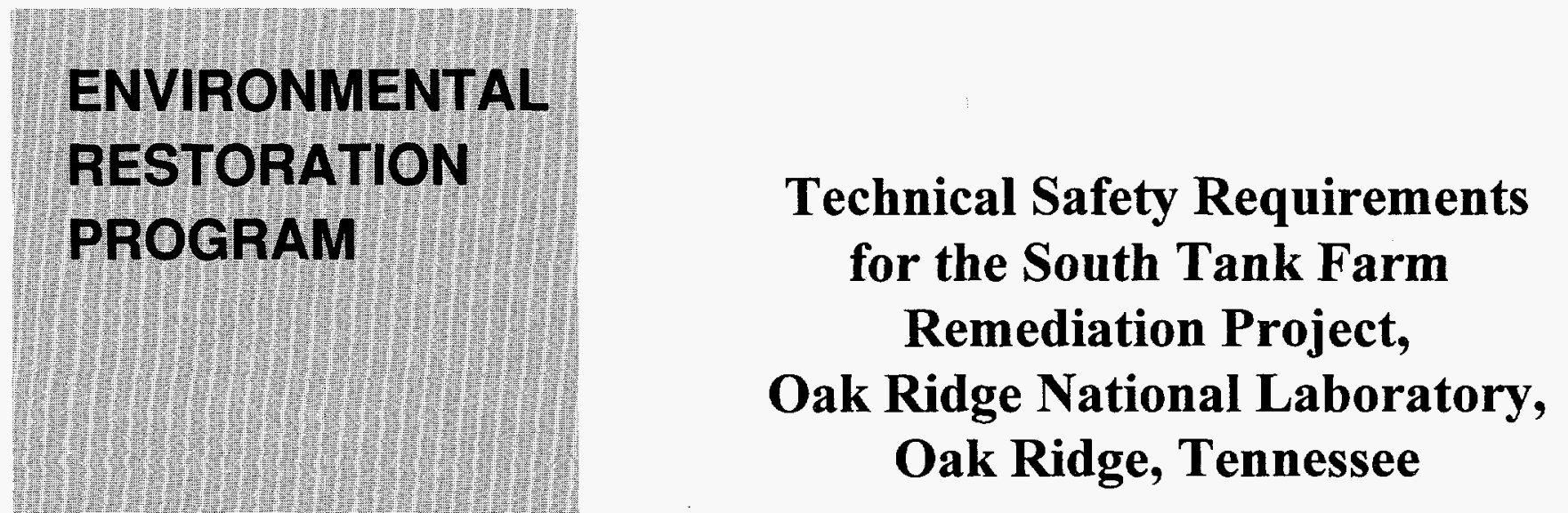

RECEIVED

….

FFR 241998

OSTI

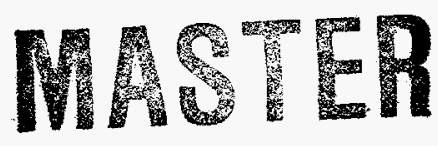

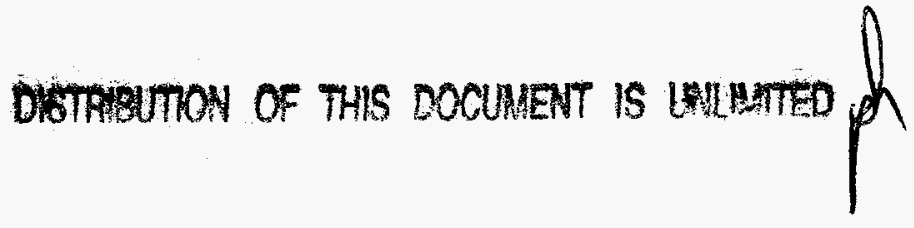

This document has been approved by the ORNL Technical Information Office

for release to the public. Date: 02/09/98 


\section{Science Applications International Corporation}

contributed to the preparation of this document and should not be considered an eligible contractor for its review. 


\section{DISCLAIMER}

This report was prepared as an account of work sponsored by an agency of the United States Government. Neither the United States Government nor any agency thereof, nor any of their employees, makes any warranty, express or implied, or assumes any legal liability or responsibility for the accuracy, completeness, or usefulness of any information, apparatus, product, or process disclosed, or represents that its use would not infringe privately owned rights. Reference herein to any specific commercial product, process, or service by trade name, trademark, manufacturer, or otherwise does not necessarily constitute or imply its endorsement, recommendation, or favoring by the United States Government or any agency thereof. The views and opinions of authors expressed herein do not necessarily state or reflect those of the United States Government or any agency thereof. 


\section{DISCLAIMER}

Portions of this document may be illegible electronic image products. Images are produced from the best available original document. 


\title{
Technical Safety Requirements for the South Tank Farm Remediation Project, Oak Ridge National Laboratory, Oak Ridge, Tennessee
}

\author{
Date Issued_February 1998
}

\author{
Prepared for the \\ U.S. Department of Energy \\ Office of Environmental Management \\ under budget and reporting code EW 20 \\ Environmental Management Activities at \\ OAK RIDGE NATIONAL LABORATORY \\ Oak Ridge, Tennessee 37831 \\ managed by \\ LOCKHEED MARTIN ENERGY SYSTEMS, INC. \\ for the \\ U.S. DEPARTMENT OF ENERGY \\ under contract DE-AC05-84OR21400
}


APPROVALS

Technical Safety Requirements

for the South Tank Farm

Remediation Project,

Oak Ridge National Laboratory,

Oak Ridge, Tennessee

(ORNL/ER-404)

Prepared by:

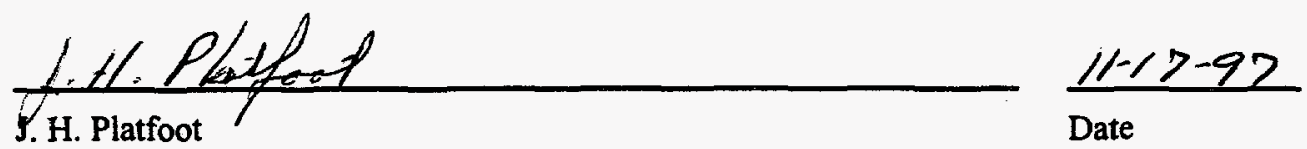

System Safety Engineering

Concurred with by:

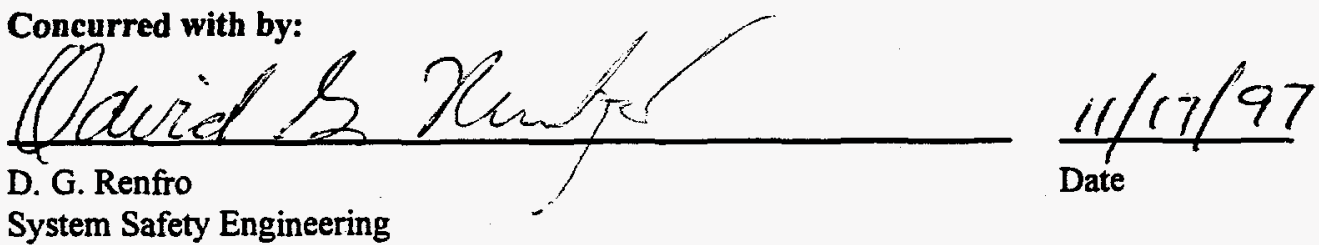

System Safety Engineering

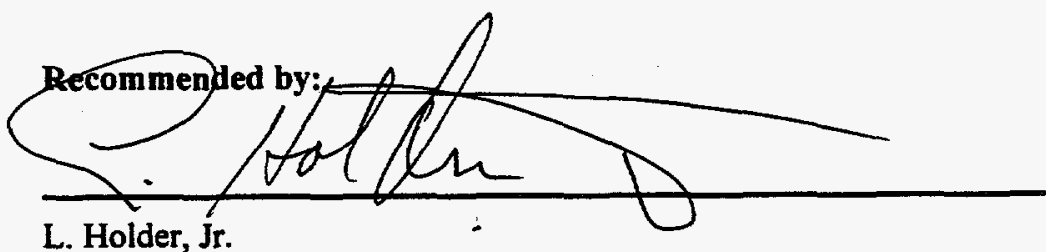

L. Holder, Jr.

South Tank Farm Facility Manager

SOar Hare

S. D. Van Hoesen

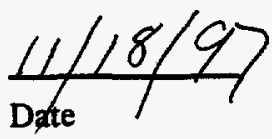

GAAT Project Manager

Approved by:

$\frac{11 / 19 / 97}{\text { Date }}$

W. D. Bneheen

W. D. Brickeen

ORNL Manager

EM SE. PAged

R. S. McKeehan

$11 / 24 / 97$

Date

for ORNL Installation Facility Safety Manager
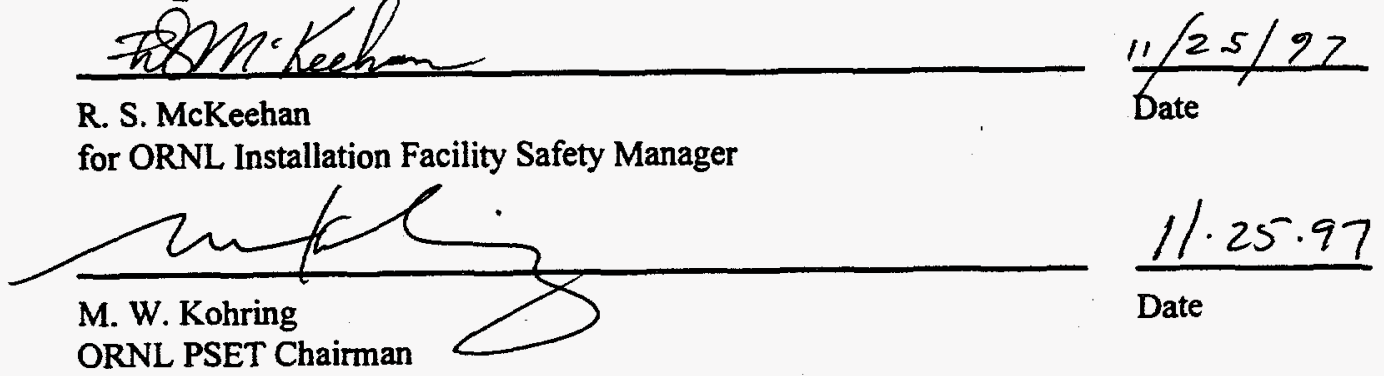


\section{APPROVALS \\ Technical Safety Requirements \\ for the South Tank Farm \\ Remediation Project, \\ Oak Ridge National Laboratory, \\ Oak Ridge, Tennessee \\ (ORNL/ER-404)}

Recommended by:

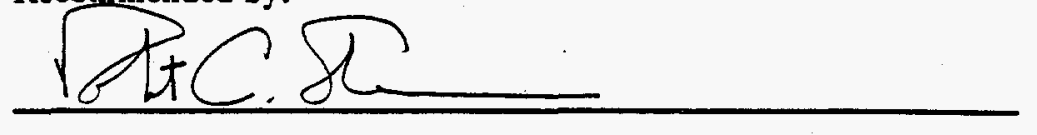

R. C. Sleeman, Director

$1 / 21 / 98$

DOE-ORO Environmental Restoration Division

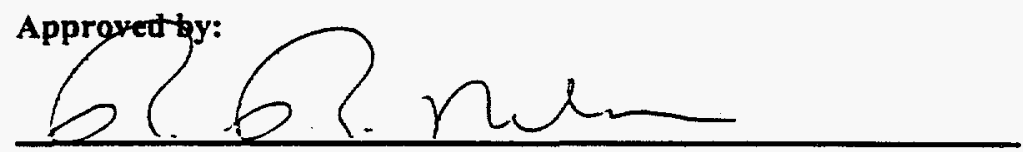

R. R. Nelson, Assistant Manager

$421 / 98$

DOE-ORO Environmental Management

Date 


\section{PREFACE}

This Technical Safety Requirements for the South Tank Farm Remediation Project, Oak Ridge National Laboratory, Oak Ridge, Tennessee (ORNL/ER-404) was prepared under Work Breakdown Structure 1.4.12.6.1.01.41.19.10 (Activity Data Sheet 3300, “Gunite and Associated Tanks Project”). 



\section{CONTENTS}

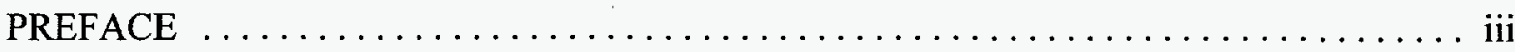

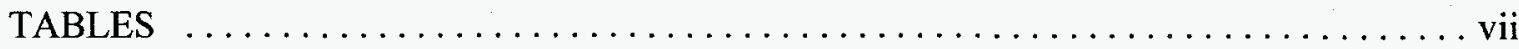

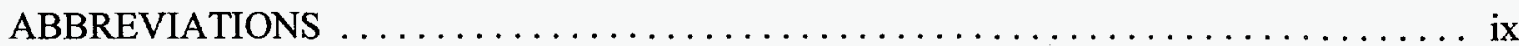

EXECUTIVE SUMMARY $\ldots \ldots \ldots \ldots \ldots \ldots \ldots \ldots \ldots \ldots \ldots \ldots \ldots \ldots \ldots \ldots \ldots \ldots \ldots$

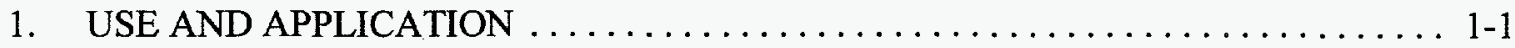

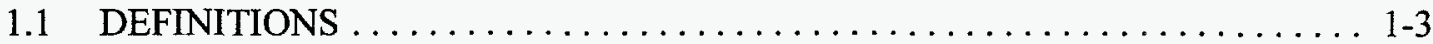

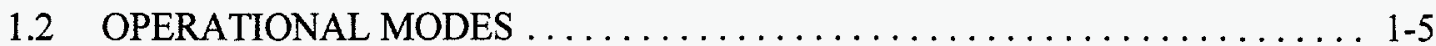

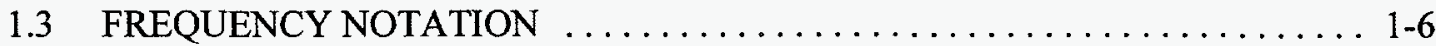

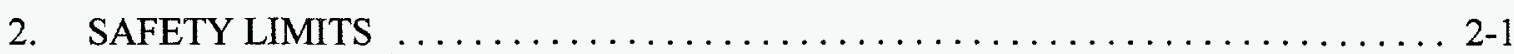

3/4. OPERATIONAL LIMITS AND SURVEILLANCE REQUIREMENTS $\ldots \ldots \ldots \ldots$ 3/4 0-1

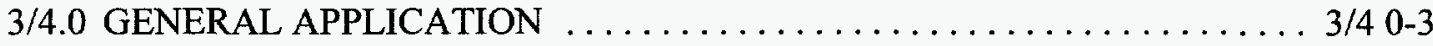

3.0.1 LIMITING CONDITIONS FOR OPERATION $\ldots \ldots \ldots \ldots \ldots \ldots .3 / 40.3$

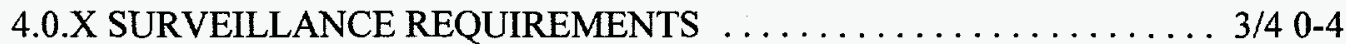

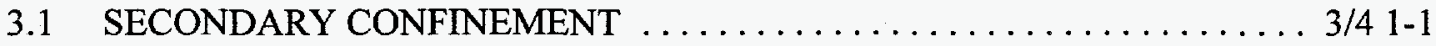

LCO 3.1.1 Secondary Confinement for Aboveground

Transfer Piping/Hoses ........................ 3/4 1-1

3.2 ISOLATION OF INTERFACING SYSTEMS $\ldots \ldots \ldots \ldots \ldots \ldots \ldots \ldots . \ldots . \ldots . \ldots .42-1$

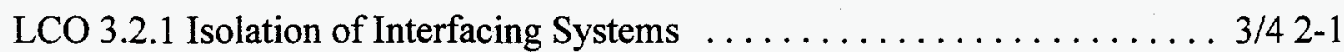

3.3 TERMINATION OF SLUDGE TRANSFER ACTIVITIES $\ldots \ldots \ldots \ldots \ldots . . \ldots 3 / 4$ 3-1

LCO 3.3.1 Multiple Control Points for Sludge Transfer

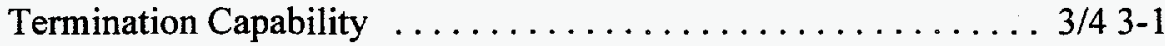

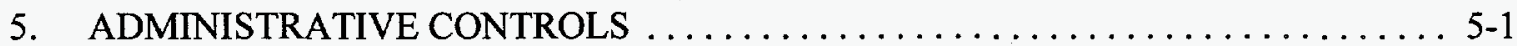

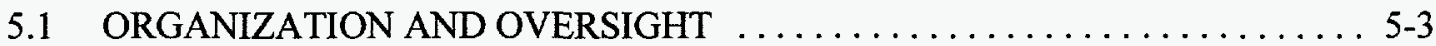

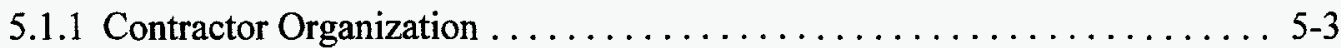

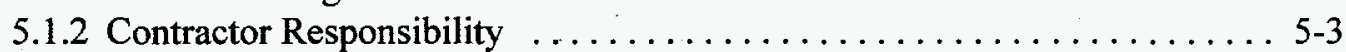

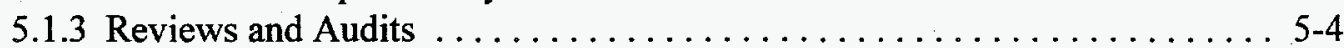

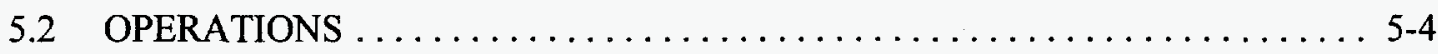

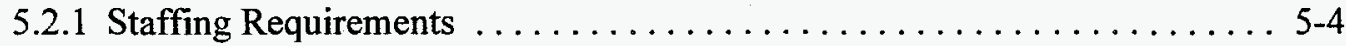

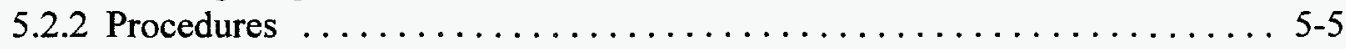

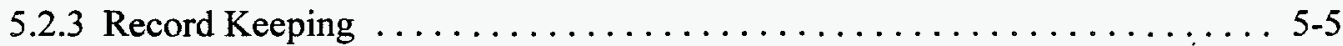

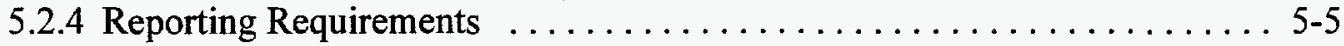

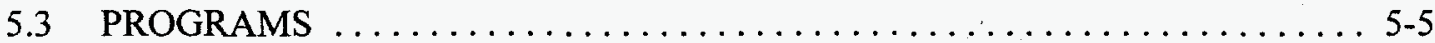

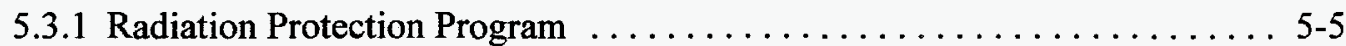

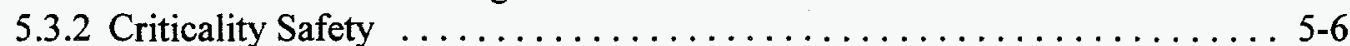

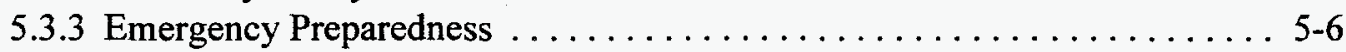

5.3 .4 Maintenance .............................. 5-6

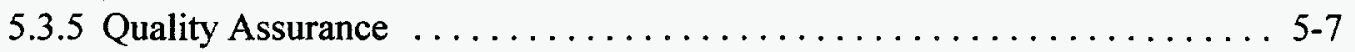


5.3.6 Configuration Management

5.4 TECHNICAL SAFETY REQUIREMENTS BASES CONTROL

$5-7$

APPENDIX A. TECHNICAL SAFETY REQUIREMENTS BASES 


\section{TABLES}

Table No.

$\underline{\text { Title }}$

$\underline{\text { Page }}$

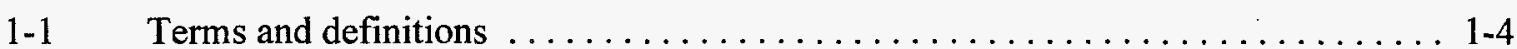

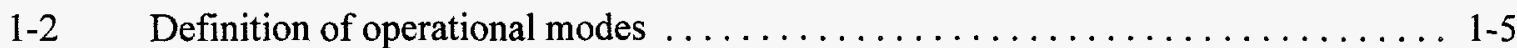

1-3 Definition of frequency terms for SURVEILLANCE REQUIREMENTS $\ldots \ldots \ldots$ 1-6

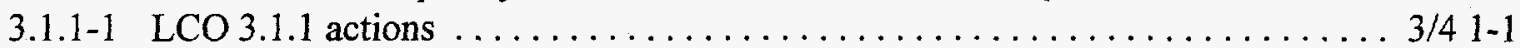

4.1.1-1 LCO 3.1 .1 SURVEILLANCE REQUIREMENTS ................ 3/4 1-1

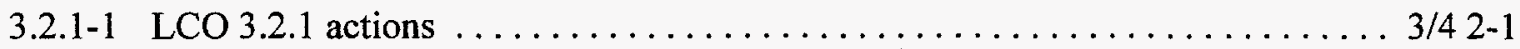

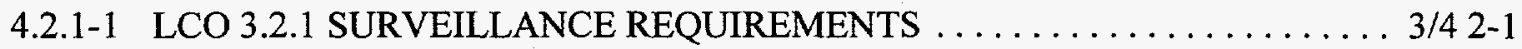

3.3.1-1 LCO 3.3.1 actions ............................... 3/4 3-1

4.3.1-1 LCO 3.4.1 SURVEILLANCE REQUIREMENTS $\ldots \ldots \ldots \ldots \ldots \ldots \ldots \ldots$ 3/4 3-1 



\begin{tabular}{|c|c|}
\hline CI & configuration item \\
\hline CSEE & confined sluicing end effector \\
\hline $\mathrm{DOE}$ & U.S. Department of Energy \\
\hline GSEE & gunite scarifying end effector \\
\hline LCS & LIMITING CONTROL SETTING \\
\hline $\mathrm{LCO}$ & LIMITING CONDITIONS FOR OPERATION \\
\hline LLLW & Liquid LOW-LEVEL WASTE \\
\hline MLDUA & Modified Light-Duty Utility Arm \\
\hline NCS & Nuclear Criticality Safety \\
\hline ORNL & Oak Ridge National Laboratory \\
\hline QA & quality assurance \\
\hline SR & SURVEILLANCE REQUIREMENT \\
\hline STF & South Tank Farm \\
\hline TSR & Technical Safety Requirement \\
\hline WAC & waste acceptance criteria \\
\hline WD\&C & Waste Dislodging and Conveyance \\
\hline
\end{tabular}





\section{EXECUTIVE SUMMARY}

\section{E.1 SOUTH TANK FARM BACKGROUND}

The South Tank Farm (STF) is a series of six, 170,000-gal underground, domed storage tanks that were placed into service in 1943. The tanks were constructed of a concrete mixture known as gunite. They were used as a portion of the Liquid LOW-LEVEL WASTE (LLLW) System for the collection, neutralization, storage, and transfer of the aqueous portion of the radioactive and/or hazardous chemical wastes produced as part of normal facility operations at Oak Ridge National Laboratory (ORNL). Although the last of the tanks was taken out of service in 1986, they have been shown by structural analysis to continue to be structurally sound. An attempt was made in 1983 to empty the tanks; however, removal of all the sludge from the tanks was not possible with the equipment and schedule available. Since removal of the liquid waste in 1983 , liquid continues to accumulate within the tanks. The in-leakage is believed to be the result of groundwater dripping into the tanks around penetrations in the domes. The tanks are currently being maintained under a Surveillance and Maintenance Program, which includes activities such as level monitoring, vegetation control, High Efficiency Particulate Air filter leakage requirement testing/replacement, sign erection/repair, pump-out of excessive liquids, and instrument calibration/maintenance.

\section{E.2 REMEDIATION PROJECT OVERVIEW}

The gunite tanks of the STF and the gunite and stainless-steel tanks in the North Tank Farm are known collectively as the Gunite and Associated Tanks. These tanks are to undergo remediation and clean-up using sludge removal techniques and equipment planned for use in other waste storage tanks throughout the U.S. Department of Energy (DOE) complex. Sludges in Tanks W-3 and W-4 in the North Tank Farm and Tanks W-5, W-6, W-7, W-8, W-9, and W-10 in the STF will be the subject of the remediation project. A technique known as confined sluicing, which uses a high-pressure, low-volume water jet integrated with a jet pump, will be used to remove the sludge. Two deployment options are used for the confined sluicing. The first is a Modified Light-Duty Utility Arm (MLDUA), which is a remotely controlled robotic arm that can be used to position and manipulate the sluicing equipment The second is a remotely operated vehicle, a tracked vehicle equipped with a manipulator gripper that is used to position and manipulate the confined sluicing equipment and a plow-type blade that is used to move sludge around the tank. In addition to the confined sluicing, scarifying, with high-pressure water cutters, may be performed to remove layers of the gunite material to remove contaminated material embedded in the walls and floors.

The MLDUA, tracked vehicle, and confined sluicing equipment transfer the sludge as a slurry out of the tank, through a Sludge Conditioning System and transfer piping to Tank W-8 and/or W-9. The Sludge Conditioning System is currently only a booster pump to transfer the slurry to the receiving tank but in the future will include a mechanical equipment unit used to ensure the slurry does not inadvertently plug the intervalley transfer line.

The STF remediation project is described and evaluated in the Safety Analysis Report for the Gunite and Associated Tanks Project Remediation of the South Tank Farm, Facility 3507, ORNL/ER-403!. 


\section{E.3 TECHNICAL SAFETY REQUIREMENTS}

The Technical Safety Requirements (TSRs) are those operational requirements that specify the operating limits and surveillance requirements, the basis thereof, safety boundaries, and the management or administrative controls necessary to ensure the safe operation of the STF remediation project. Effective implementation of TSRs will limit to acceptable levels the risks to the public and workers from uncontrolled releases of radioactive or other hazardous material. TSRs are required for nuclear facilities by DOE Order $5480.22^{2}$. The TSRs are derived from the safety analysis as outlined in Chap. 5 of the Safety Analysis Report.

The TSRs place Limiting Conditions for Operation (LCO) and Surveillance Requirements on the following safety-significant systems, structures, or components in the STF remediation project.

1. Secondary confinement for primary aboveground transfer piping/hoses for the (a) Waste Dislodging and Conveyance System, (b) Transfer/Valving Box, and the (c) Sludge Conditioning System. The secondary confinement will collect the releases from leaks, etc., in the primary aboveground transfer piping or hoses and direct it back to one of the tanks to reduce the consequences of the releases.

2. Check valves for the isolation of flush lines interfacing with the primary transfer line to prevent process fluid from backflowing into the process water system if the normal isolation valve leaks, fails open, or is inadvertently left open.

3. Multiple control points that provide three physically separate and independent means of terminating the sludge transfer operations within $40 \mathrm{~min}$ to limit the consequences of the releases to those analyzed in the Safety Analysis Report .

The TSRs also place Administrative Controls on the overall operation of the STF remediation project. These include organization and oversight, staffing, training, procedures, record keeping, occurrence reporting, and safety management programs.

\section{E.4 REFERENCES}

1. ORNL/ER-403, Safety Analysis Report for the Gunite and Associated Tanks Project Remediation of the South Tank Farm, Facility 3507, Lockheed Martin Energy Systems, Inc., Oak Ridge, Tennessee, November 1997.

2. DOE Order 5480.22, Technical Safety Requirements, U.S. Department of Energy, Washington, D.C., September 15, 1992. 
SECTION 1. USE AND APPLICATION 



\section{USE AND APPLICATION}

The South Tank Farm (STF) is a series of six 170,000-gal underground, domed storage tanks, which were placed into service in 1943. The tanks were constructed of a concrete mixture known as gunite. They were used as a portion of the Liquid LOW-LEVEL WASTE (LLLW) System for the collection, neutralization, storage, and transfer of the aqueous portion of the radioactive and/or hazardous chemical wastes produced as part of normal facility operations at Oak Ridge National Laboratory (ORNL). The last of the tanks was taken out of service in 1986.

The gunite tanks of the STF and the gunite and stainless steel tanks in the North Tank Farm are known collectively as the Gunite and Associated Tanks. These tanks are to undergo remediation and clean-up by using sludge removal techniques and equipment planned for use in other waste storage tanks throughout the U.S. Department of Energy (DOE) complex. Tanks W-5, W-6, W-7, W-8, W-9, and $\mathrm{W}-10$ in the STF will be the subject of the remediation project. Sludges in Tanks W-3 and W-4 will be transferred to the STF sometime before or during the STF Remediation Project. A technique known as confined sluicing, which uses a high pressure, low-volume water jet integrated with a jet pump, will be used to remove the sludge. Two deployment options are used for the confined sluicing. The first is a Modified Light-Duty Utility Arm (MLDUA), which is a remotely controlled robotic arm that can be used to position and manipulate the sluicing equipment. The second is a remotely operated vehicle. The tracked vehicle, equipped with a plow-type blade, is used to position and manipulate the confined sluicing equipment and to move sludge around the tank with the blade. The top layer of gunite in each tank may be removed through the use of a gunite scarifier to remove embedded contamination. The removed material will be added to the sludge in the tanks and transferred, along with the sludge, out of the tanks.

The MLDUA, tracked vehicle, and confined sluicing equipment transfer sludge as a slurry out of the tank through transfer piping to Tank W-8 or W-9. From the tank, the slurry will be transferred through a Sludge Conditioning System and ultimately transferred to the Melton Valley Storage Tanks in Building 7830. The Sludge Conditioning System is a mechanical equipment unit used to condition the sludge heels as necessary to ensure they do not inadvertently plug the transfer line and to ensure they meet the appropriate requirements for the ORNL LLLW System waste acceptance criteria (WAC).

All requirements in this Technical Safety Requirement (TSR) document apply to an operating facility/system unless otherwise specified.

\subsection{DEFINITIONS}

Table 1-1 defines the terms used in this TSR. Terms defined in this list appear in uppercase throughout the document. 
Table 1-1. Terms and definitions

\begin{tabular}{l} 
Term \\
\hline ADMINISTRATIVE \\
CONTROLS \\
IMMEDIATELY \\
LIMITING \\
CONDITIONS FOR \\
OPERATION (LCO) \\
LIMITING CONTROL \\
SETTING (LCS)
\end{tabular}

LOW-LEVEL WASTE

OPERABLE/

OPERABILITY

QUALIFIED

OPERATOR

SAFETY LIMIT

SURVEILLANCE

REQUIREMENTS (SRs)
Provisions relating to organization and management procedures, record keeping, assessment, and reporting necessary to ensure the safe operation of a facility.

The minimum amount of time required to safely complete the activity and not to exceed 1 hour.

The lowest functional capability or performance levels of safety-related structures, systems, and their support systems required for normal, safe operation of the facility.

Settings on safety-related structures, systems, and components that control process variables to prevent exceeding SAFETY LIMITS.

Waste that contains radioactivity and is stored in the ORNL LLLW System storage tanks or pipelines or meets the ORNL LLLW WAC or an approved deviation to the ORNL LLLW WAC.

A system or component is OPERABLE when it and its support systems and components are capable of performing their intended function or intended support function, respectively. A system or component is considered OPERABLE when the required SURVEILLANCE has been accomplished in accordance with the required frequency and when there is no indication of inoperability. When a system or component is determined to be incapable of performing its intended safety function(s), the declaration of inoperability shall be immediate.

Any individual who has successfully completed the training and has been certified by the examiner and facility manager as qualified to operate the system in question.

Limits on process variables associated with physical barriers, generally passive that are necessary for the intended facility function and are found to be required to guard against the uncontrolled release of radioactivity and other hazardous materials. Process variables subject to SAFETY LIMITS are measurable parameters that, individually or in combination, reflect the basic hazard for which controls or limits are specified.

Requirements relating to testing, calibration, or inspection to ensure that the necessary OPERABILITY of systems and components is maintained or that operations are within specified SAFETY LIMITS, LCSs, and LCO. 


\begin{tabular}{|c|c|}
\hline Term & Definition \\
\hline TSR VIOLATION & $\begin{array}{l}\text { A TSR VIOLATION is reportable to DOE in accordance with DOE Order } \\
\text { 232.1. A TSR VIOLATION is defined as including one or a combination } \\
\text { of the following: } \\
\text { - Exceeding a SAFETY LIMIT } \\
\text { - Failure to take the required actions within the specified time limits for } \\
\text { the following: } \\
\text { - Exceeding an LCS } \\
\text { - Failure to meet an LCO } \\
\text { Failure to perform an SR within the required interval. NOTE: Failure } \\
\text { to meet acceptance criteria associated with an SR will not be } \\
\text { considered a TSR VIOLATION but will result in the subject } \\
\text { control/equipment being declared inoperable. Once the } \\
\text { control/equipment is declared inoperable, the associated LCO and its } \\
\text { action statements must be invoked. } \\
\text { Failure to comply with an ADMINISTRATIVE CONTROL. } \\
\text { NOTE: Failure to comply with individual procedural requirements of } \\
\text { the programs described in Sect. } 5.4 \text { will not be considered a TSR } \\
\text { VIOLATION provided the noncompliances are not the result of a } \\
\text { widespread failure to establish and implement the programs (i.e., } \\
\text { "programmatic breakdown"). }\end{array}$ \\
\hline
\end{tabular}

\subsection{OPERATIONAL MODES}

Table 1-2 defines the operational modes.

Table 1-2. Definition of operational modes

\begin{tabular}{lll}
\hline Mode & \multicolumn{1}{c}{ Title } & \multicolumn{1}{c}{ Definition } \\
\hline 1. & Operation Mode & $\begin{array}{l}\text { Inventory above category } 3 \text { quantities present and process water to confined } \\
\text { sluicing end effector (CSEE), gunite scarifying end effector (GSEE), or jet } \\
\text { pump (when in tank) is not isolated. }\end{array}$ \\
2. & $\begin{array}{l}\text { Warm Standby } \\
\text { Mode }\end{array}$ & $\begin{array}{l}\text { Inventory above category 3 quantities present and process water isolated to } \\
\text { CSEE, GSEE, and jet pump (when in tank). MLDUA, remotely operated } \\
\text { vehicle, and Waste Dislodging and Conveyance (WD\&C) System powered } \\
\text { up and process water which can cause tank overflow not isolated. }\end{array}$ \\
& $\begin{array}{l}\text { Cold Standby } \\
\text { Mode }\end{array}$ & $\begin{array}{l}\text { Inventory above category 3 quantities present and (1) process water isolated } \\
\text { to CSEE, GSEE, or jet pump (when in tank) and (2) MLDUA, remotely } \\
\text { operated vehicle, and WD\&C System powered down and (3) all process } \\
\text { water which can cause tank to overflow isolated. }\end{array}$ \\
\hline
\end{tabular}




\subsection{FREQUENCY NOTATION}

Frequency terms for SURVEILLANCE REQUIREMENTS are defined in Table 1-3.

Table 1-3. Definition of frequency terms for SURVEILLANCE REQUIREMENTS

\begin{tabular}{ll}
\hline \multicolumn{1}{c}{ Term } & \multicolumn{1}{c}{$\begin{array}{c}\text { Minimum frequency } \\
\text { (periodicity notation) }\end{array}$} \\
\hline Annually & At least once per 365 days \\
Semiannually & At least once per 184 days \\
Quarterly & At least once per 92 days \\
Monthly & At least once per 31 days \\
Weekly & At least once per 7 days \\
Daily & At least once per 24 hours \\
Each Shift & At least once per 12 hours \\
\hline
\end{tabular}




\section{SECTION 2. SAFETY LIMITS}





\section{SAFETY LIMITS}

There are no SAFETY LIMITS associated with the South Tank Farm Remediation Project. 


AND SURVEILLANCE REQUIREMENTS 



\section{3/4. OPERATIONAL LIMITS AND SURVEILLANCE REQUIREMENTS}

There are no LIMITING CONTROL SETTINGS associated with operations in the South Tank Farm Remediation Project. This section applies only to the LIMITING CONDITIONS FOR OPERATIONS and SURVEILLANCE REQUIREMENTS specified for safe operation of the South Tank Farm Remediation Project.

\section{3/4.0 GENERAL APPLICATION}

\section{OPERATING LIMITS}

\subsubsection{LIMITING CONDITIONS FOR OPERATION}

3.0.1.1 Compliance with the LCOs contained in the succeeding requirements is demanded during the operational modes or other conditions specified therein; except that upon failure to meet the LCOs, the associated action statement shall be met.

3.0.1.2 Noncompliance with a requirement (TSR VIOLATION) shall exist when the demands of the LCO and associated action statements are not met within the specified time intervals. If the LCO is restored before expiration of the specified time intervals, completion of the action statement is not required.

3.0.1.3 When a LCO is not met, except as provided in the associated action statement, within 1 hour, action shall be initiated to place the unit in a mode in which the requirement does not apply.

Where corrective actions are completed that permits operation under the action statement, the action may be taken in accordance with the specified time limits as measured from the time of failure to meet the LCO. Exceptions are stated in the individual requirements.

3.0.1.4 Entry into an operational mode or other specified condition shall not be made unless the conditions for the LCO are met without reliance on provisions contained in the action statement. This provision shall not prevent passage through or to operational modes as required to comply with the action statement. Exceptions are stated in the individual requirements. 


\section{SURVELLANCE REQUIREMENTS}

4.0.1 SURVEILLANCE REQUIREMENTS shall be met during the operational modes or other conditions specified for the individual LCOs unless otherwise stated in an individual SURVEILLANCE REQUIREMENT.

4.0.2 Failure to perform a SURVEILLANCE REQUIREMENT within the specified time interval (TSR VIOLATION) shall constitute a failure to meet the OPERABILITY requirements for an LCO. Exceptions are stated in the individual requirements. SURVEILLANCES 'do not have to be performed on inoperable equipment.

4.0.3 Entry into an operational mode or other specified condition shall not be made unless the SURVEILLANCE REQUIREMENTS associated with the LCO have been performed within the stated SURVEILLANCE interval or as otherwise specified. 


\subsection{SECONDARY CONFINEMENT}

\section{LCO 3.1.1 Secondary Confinement for Aboveground Transfer Piping/Hoses}

LCO: Primary transfer lines in the components listed below and their connecting hoses and the hose from the Sludge Conditioning System to the receiving tank shall have an OPERABLE secondary confinement, which has a leak rate of less than $5 \mathrm{gal} / \mathrm{min}$ :

1. WD\&C

2. Transfer/Valving Box

3. Sludge Conditioning System

APPLICABILITY: This LCO applies in Mode 1.

Table 3.1.1-1. LCO 3.1.1 actions

\begin{tabular}{lll}
\hline \multicolumn{1}{c}{ Condition } & \multicolumn{1}{c}{ Required action } & Completion time \\
\hline $\begin{array}{l}\text { Secondary confinement for } \\
\text { above ground piping/hoses is } \\
\text { not OPERABLE during Mode 1. }\end{array}$ & $\begin{array}{l}\text { Restore secondary confinement to an } \\
\text { OPERABLE status }\end{array}$ & IMMEDIATELY \\
& \multicolumn{1}{c}{ OR } & \\
& Enter Mode 2 or Mode 3 & 1 hour \\
\hline
\end{tabular}

Table 4.1.1-1. LCO 3.1.1 SURVEILLANCE REQUIREMENTS

\begin{tabular}{lll}
\hline No. & SURVEILLANCE REQUIREMENT & Frequency \\
\hline 4.1.1.1 & $\begin{array}{l}\text { Visually inspect the secondary confinement } \\
\text { equipment or perform a decay pressure test on } \\
\text { the secondary confinement hoses for damage or } \\
\text { improper configuration. }\end{array}$ & Daily \\
& $\begin{array}{l}\text { AND } \\
\text { following any maintenance activity or } \\
\text { other event that could affect the integrity of } \\
\text { the secondary confinement }\end{array}$ \\
\hline
\end{tabular}




\subsection{ISOLATION OF INTERFACING SYSTEMS}

\section{LCO 3.2.1 Isolation of Interfacing Systems}

LCO: Flush lines interfacing with the primary transfer line shall be equipped with an OPERABLE check valve to prevent process fluid backflow into the process water system. (Applies to check valves CV-105 and CV-330.)

APPLICABILITY: This LCO applies in Mode 1.

Table 3.2.1-1. LCO 3.2.1 actions

\begin{tabular}{lcl}
\hline CONDITON & REQUIRED ACTION & \multicolumn{1}{c}{ COMPLETION TIME } \\
\hline $\begin{array}{l}\text { Check valve is not } \\
\text { OPERABLE during Mode 1. }\end{array}$ & Restore to an OPERABLE status & IMMEDIATELY \\
& OR & \\
& Enter Mode 2 or Mode 3 & 1 hour \\
\hline
\end{tabular}

Table 4.2.1-1. LCO 3.2.1 SURVEILLANCE REQUIREMENTS

\begin{tabular}{|c|c|c|}
\hline No. & SURVEILLANCE REQUIREMENT & Frequency \\
\hline \multirow[t]{3}{*}{4.2 .1 .1} & $\begin{array}{l}\text { Functionally test the check valves used to } \\
\text { isolate interfacing system }\end{array}$ & Annually \\
\hline & & $\underline{\text { AND }}$ \\
\hline & . & $\begin{array}{l}\text { following any maintenance activity or other } \\
\text { event that could affect check valve } \\
\text { OPERABILITY }\end{array}$ \\
\hline
\end{tabular}




\subsection{TERMINATION OF SLUDGE TRANSFER ACTIVITIES}

\section{LCO 3.3.1 Multiple Control Points for Sludge Transfer Termination Capability}

LCO: The following three physically separate, independent OPERABLE control points shall be available to terminate sludge transfer operations:

1. the $480 \mathrm{~V}$ supply breaker to the jet pump high pressure pump (device number 1-33-5-2-4-1),

2. the process water isolation valve $\mathrm{HV}-111 \mathrm{C}$ on the process water skid, and

3. the $480 \mathrm{~V}$ emergency disconnect breaker supply to the transformer trailer supply to the jet pump high pressure pump (device number 1-33-5-2).

APPLICABILITY: This LCO applies in Mode 1 .

Table 3.3.1-1. LCO 3.3.1 actions

\begin{tabular}{lcl}
\hline \multicolumn{1}{c}{ CONDITION } & REQUIRED ACTION & \multicolumn{1}{c}{ COMPLETION TIME } \\
\hline $\begin{array}{l}\text { Any Control Point is not } \\
\text { OPERABLE during Mode 1. }\end{array}$ & Restore to an OPERABLE status & IMMEDIATELY \\
& OR & \\
& Enter Mode 2 or Mode 3 & 1 hour \\
\hline
\end{tabular}

Table 4.3.1-1. LCO 3.4.1 SURVEILLANCE REQUIREMENTS

\begin{tabular}{|c|c|c|}
\hline No. & SURVEILLANCE REQUIREMENT & Frequency \\
\hline \multirow[t]{2}{*}{ 4.3.1.1 } & $\begin{array}{l}\text { Visually inspect control equipment for } \\
\text { physical damage, accessibility, or } \\
\text { changes in configuration. }\end{array}$ & Daily \\
\hline & & $\begin{array}{l}\text { following any maintenance activity or other event } \\
\text { that could affect control equipment } \\
\text { OPERABILITY or accessibility }\end{array}$ \\
\hline \multirow[t]{3}{*}{ 4.3.1.2 } & Functionally test control equipment. & Annually \\
\hline & & $\underline{\text { AND }}$ \\
\hline & & $\begin{array}{l}\text { following any maintenance activity or other } \\
\text { event that could affect control equipment } \\
\text { OPERABILITY }\end{array}$ \\
\hline 4.3.1.3 & $\begin{array}{l}\text { Visually inspect locations of control } \\
\text { points to ensure that they are physically } \\
\text { separated by at least } 30 \mathrm{ft} \text {. }\end{array}$ & $\begin{array}{l}\text { Following relocation of the either the process } \\
\text { water skid or the jet pump high pressure pump } \\
\text { skid }\end{array}$ \\
\hline
\end{tabular}



SECTION 5. ADMINISTRATIVE CONTROLS 



\section{ADMINISTRATIVE CONTROLS}

\subsection{ORGANIZATION AND OVERSIGHT}

\subsubsection{Contractor Organization}

Lines of authority, responsibility, and communication shall be established and defined for the STF Remediation Project management levels, through intermediate levels to and including all safety and operating organization positions. These relationships shall be documented and updated, as appropriate, in the form of organizational charts, functional descriptions of project responsibilities and relationships, and job descriptions for key personnel positions, or in equivalent forms of documentation.

The STF Remediation Project manager has responsibility for the overall safe operation and maintenance of the STF Remediation Project systems and equipment. Safe operation shall include, as necessary, responsibility for the installation of sludge removal equipment into the individual tanks, equipment configuration, sludge removal and transfer, and interface requirements with other organizations and facilities to ensure availability of essential services.

The Quality Assurance (QA) Specialists for STF Remediation Project represent their ORNL Office of Quality Services and have the responsibility for reviewing and reporting on the QA systems for the project.

The ORNL Operations, Environmental, Safety, and Health Compliance Directorate furnishes the expertise to advise the STF Remediation Project on matters relating to environmental monitoring, industrial hygiene, radiation monitoring, radiation protection, and compliance with U.S. Environmental Protection Agency, Resource Conservation and Recovery Act, and DOE regulations.

The Office of Operational Readiness and Facility Safety represents the ORNL Director in matters of facility safety, including matters of criticality safety, and is under the authority of the ORNL Director.

Other organizations may supply craft personnel, heavy equipment operators, truck drivers, laborers, etc. as needed to support STF Remediation Project operations. All personnel doing work associated with the STF Remediation Project shall be under the supervision of STF Remediation Project personnel.

\subsubsection{Contractor Responsibility}

The STF Remediation Project manager or designee shall be responsible for safe operation of the STF Remediation Project. Safe operation shall include, as necessary, responsibility for equipment installation into the tanks, equipment configuration and operation, sludge removal and transfer, and interface requirements with other organizations and facilities to ensure availability of essential services. 


\subsubsection{Reviews and Audits}

Operational readiness reviews, readiness assessments, or internal management assessments shall be performed for selected new activities as identified by the project manager.

Safety review programs shall be established to ensure and verify safety in the areas of radiation protection, criticality safety, emergency preparedness, and facility safety analysis.

Periodic safety audits and safety reviews shall be conducted by independent individuals, committees, or groups.

Unreviewed Safety Question Determinations or Screenings shall be performed to determine if proposed changes, tests, experiments, and as-found conditions could result in the facility being outside its authorization basis.

Changes to equipment design or to operating practices that require changes to this TSR shall not be implemented before DOE approval of the associated changes to the TSR except as discussed in Sect. 5.4.

\subsection{OPERATIONS}

\subsubsection{Staffing Requirements}

\subsubsection{Minimum operations shift complement}

The minimum personnel in facility during Mode 1 operations shall be one QUALIFIED BOP Field OPERATOR for the specific operation. (Note that the Safety Analysis Report analysis states that, as a defense-in-depth measure, an operator is also required to be in the facility during Mode 2 operations. None of the Mode 2 events resulted in consequences that require TSR controls.)

\subsubsection{Operating support}

The STF Remediation Project manager shall maintain the capability to contact additional support as needed during operations, including personnel such as Lab Shift Superintendent and the Nuclear Criticality Safety Organization.

\subsubsection{Facility staff qualifications and training}

Operators should have a high school diploma with satisfactory achievement in technical courses and a minimum of 2 years experience in engineering, science, laboratory work, or the equivalent in related fields. Experience and education may be substituted as appropriate.

All operating personnel shall complete a program of classroom training and/or on-the-job training that teaches them to perform their duties in a manner that ensures the facility's compliance with operational requirements.

Operating personnel not fully trained will be supervised by a QUALIFIED OPERATOR when performing activities requiring qualification. 
Support personnel from other organizations shall be trained as applicable to perform their duties in safe, efficient, and correct manner to meet state and federal requirements.

All personnel assigned to the facility shall participate in a review of the training every 2 years.

\subsubsection{Procedures}

Procedures shall be established, implemented, and maintained for all phases of normal operation and emergency operation.

Procedures shall identify the responsible implementing organizations and/or individuals and the actions required. Procedures shall be kept current by formal issuance of revisions as conditions change. New procedures and revisions to procedures shall be subject to a documented review and approved by the facility manager or designee. Current revisions of procedures approved for use shall be retrievable and placed on controlled distribution to identified users.

\subsubsection{Record Keeping}

In addition to the requirements of applicable regulations, and in no way substituting therefore, records and logs shall be prepared for at least the following items and retained for at least the period indicated in parenthesis:

- Normal facility operation (1 year)

- Principal maintenance activities (1 year)

- Occurrence Reports as required by DOE Order 232.1, Occurrence Reporting and Processing of Operations Information (1 year)

- $\quad$ Training records (1 year)

- Equipment and component SURVEILLANCE activities required by the TSRs ( 3 years)

\subsubsection{Reporting Requirements}

In the event of a reportable occurrence, actions will be taken as specified in DOE Order 232.1.

\subsection{PROGRAMS}

\subsubsection{Radiation Protection Program}

A radiation protection program shall be established, implemented, and maintained. The radiation protection program has the following objectives:

- maintaining radiation exposure at levels that are as low as reasonably achievable,

- limiting internal and external radiation exposure of occupational workers, 
- monitoring and recording occupational exposure,

- labeling radioactive materials,

- posting and establishing entry control programs for areas where elevated radiation fields may be present, and

- $\quad$ providing periodic radiation safety training.

\subsubsection{Criticality Safety}

A criticality safety program shall be established, implemented, and maintained. The criticality safety program has the following objectives:

- The Nuclear Criticality Safety (NCS) of operations involving fissionable materials is addressed and reviewed if there are fissionable nuclide quantities exceeding a threshold quantity.

- The need for NCS controls is identified and the controls are implemented when required.

- Operations involving fissionable materials are performed by trained personnel as specified in the applicable NCS Approval.

- NCS inspections/audits are performed.

- NCS infractions are reported and corrected.

\subsubsection{Emergency Preparedness}

An emergency preparedness program shall be established, implemented, and maintained. The emergency preparedness program has the following objectives:

- develop and maintain emergency planning, preparedness, and response capabilities, as well as effective public and interagency communications, to minimize the consequence to workers, national security, the public, and the environment from incidents involving DOE operations;

- respond to emergencies in an effective and timely manner to mitigate the consequences and bring the emergency situation under control; and

- provide support, within resource constraints, to other local, state, tribal, and Federal agencies and international organizations, as requested, and in accordance with pertinent Federal regulations and plans, appropriate interagency agreements, and international conventions.

\subsubsection{Maintenance}

A maintenance program shall be established, implemented, and maintained. The maintenance program has the following objectives:

- structures, systems, and components important to safe operation are subject to a maintenance program to meet or exceed their design requirements throughout their life; 
- periodic inspection of structures, systems, components, and equipment is performed to determine deterioration that threatens performance and/or safety; and

- primary responsibility, authority, and accountability for the direction and management of the maintenance programs for all property reside with the line management assigned direct programmatic responsibility.

\subsubsection{Quality Assurance}

A QA program shall be established, implemented, and maintained. The QA program has the following objectives:

- work is performed to established technical standards and administrative requirements;

- personnel are trained and qualified to perform their assigned work;

- procured items and services meet established configuration item requirements, if any;

- $\quad$ sufficient records are maintained to preserve the technical baseline documentation; and

- periodic assessments of the QA program and its performance are conducted.

\subsubsection{Configuration Management}

A configuration management program shall be established, implemented, and maintained. The configuration management program has the following objectives:

- configuration items (CIs) and the requirements for each $\mathrm{CI}$ are identified, documented, and maintained;

- activities and changes are controlled to ensure that $\mathrm{CI}$ requirements are met; and

- capability for storage and retrieval of designated CI documents and records is provided.

\subsection{TECHNICAL SAFETY REQUIREMENTS BASES CONTROL}

Changes may be made to the TSR Bases without prior DOE approval provided the changes do not involve any of the following:

1. a change in the TSR;

2. a change to the Safety Analysis Report that involves an Unreviewed Safety Question as defined in DOE Order 5480.21; or

3. a change to the way that OPERABILITY or the TSR could be met, applied, or interpreted. 
Proposed changes that meet the criteria of 1,2 , or 3 above shall be reviewed and approved by DOE before implementation. Changes to the TSR Bases that may be implemented without prior DOE approval will be provided to DOE at least annually. 
APPENDIX A. TECHNICAL SAFETY REQUIREMENT BASES 



\subsection{SECONDARY CONFINEMENT}

\section{LCO 3.1.1 Secondary Confinement for Aboveground Transfer Piping/Hoses}

\section{BASES:}

Calculations performed in support of the PHA demonstrate that releases of slurry at $5 \mathrm{gal} / \mathrm{min}$ will result in consequences that do not exceed on-site or off-site analysis guidelines. Requiring secondary confinement that can withstand leaks from primary confinement at $100 \%$ of the transfer rate through the system without releasing more than $5 \mathrm{gal} / \mathrm{min}$ ensures that consequences resulting from failure of primary confinement system equipment will not exceed analysis guidelines.

The safety analysis also demonstrates that releases of slurry at $100 \%$ of the transfer rate through the waste dislodging and conveyance confinement box will result in consequences that will exceed on-site analysis guidelines if allowed to continued for more than $40 \mathrm{~min}$. A loss of secondary confinement does not necessarily indicate a failure of the primary confinement. Requiring termination of the sludge transfer process within 1 hour of detection of loss of secondary confinement provides adequate assurance that the on-site analysis guidelines will not be exceeded.

\section{SR 4.1.1.1 Visual inspection or pressure decay test of Secondary Confinement}

\section{BASES:}

The confinement requirement for the secondary confinement features is that it will contain leaks from the primary confinement without leaking more than $5 \mathrm{gal} / \mathrm{min}$. Degradation of the secondary confinement box (from physical damage or misconfigured equipment) such that it cannot meet this performance requirement should be visually detectable. Requiring a visual inspection of the secondary confinement equipment daily during transfer activities and following any maintenance activity or other event that could affect the integrity of the secondary confinement provides adequate assurance that the secondary confinement box will provide its intended safety function during sludge transfer activities. The visual inspection will include, at a minimum, (1) all inspection covers are in place with seals, (2) no visible damage to welds or mechanical joints, and (3) no visible penetrations or cracks in the confinement barrier.

Some of the transfer hoses may be located inside of a protective enclosure such as a concrete tray. A daily inspection of these hoses is not reasonable. Instead of performing a visual inspection, a pressure decay test of the secondary confinement hoses may be conducted. The internal pressure between the primary transfer hose and the secondary confinement hose will be raised to between 15-20 psig. If the pressure does not decay to below 12 psig within 3 minutes, the secondary confinement hose is capable of performing its safety function. 


\subsection{ISOLATION OF INTERFACING SYSTEMS}

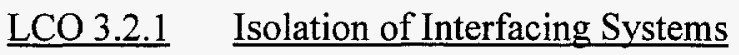

\section{BASES:}

Interfacing systems are equipped with an isolation valve that is normally closed during sludge transfer operations. In addition, the interfacing systems are normally operated at higher pressures than the process equipment to ensure that process liquids do not flow into the interfacing systems. An additional measure of assurance that liquid LOW-LEVEL WASTE will not be released in this manner is the requirement that an OPERABLE check valve be present on the interfacing system piping.

\section{$\underline{\text { SR 4.2.1.1 } \quad \text { Check valve tests }}$}

The process system to which the interfacing systems connect presents a nonhostile environment for the check valves. The process fluid is clean water. Therefore, annual testing of the check valves on the interfacing piping provides adequate assurance that they will be capable of providing their safety function during sludge transfer operations. The following check valves are to be funtionally tested:

CV-105 Flush line check valve to transfer line in the transfer/valving box.

CV-330 Flush line to the booster pump system. 


\section{LCO 3.3 TERMINATION OF SLUDGE TRANSFER ACTIVITIES}

\section{$\underline{\text { LCO 3.3.1 }}$ Multiple control points for sludge transfer termination capability}

\section{BASES:}

The safety analysis has shown that a release of $100 \%$ of the transfer rate through the sludge transfer system results in consequences that can exceed analysis guidelines if it is allowed to continue for longer than $40 \mathrm{~min}$. Therefore, it is essential that the capability to terminate sludge transfer operations be maintained for all credible accident scenarios. Requiring a minimum of three physically separate and independent control points provides adequate assurance that the ability to quickly shut down transfer operations will be maintained during all credible operating and accident conditions. The transfer process may be shut down by removing power to the high pressure jet pump supply pump by opening the pump disconnect switch, opening the supply breaker on pole \#6, or closing the process water isolation valve to the high pressure jet pump supply pump on the process water skid.

\section{SR 4.3.1.1 Visual inspection of control equipment}

\section{BASES:}

A visual inspection of all control points ensures that equipment is accessible and has not been damaged or misconfigured. Requiring a visual inspection of the control equipment daily during transfer activities and following any maintenance or other event that could affect control function or accessibility provides adequate assurance that shutdown capability will be maintained during sludge transfer operations.

\section{SR 4.3.1.2 Functional test of control equipment}

\section{BASES:}

The valve, disconnect switch, and breaker used to shut down transfer operations are highly reliable commercial equipment that operate in a nonharsh environment. The valve, disconnect switch, and emergency disconnect breaker are devices that normally do not have continuously moving parts. When required to operate, the operations within the item are simple and use the force applied by the operator on a lever. In commercial and industrial applications, these types of components are able to go without operation for several years without affecting their ability to be operated when needed. Annual tests of the control equipment provides adequate assurance that they will be capable of providing their intended safety function during sludge transfer activities.

\section{$\underline{\text { SR 4.3.1.3 Visual inspection of control point separation distance }}$}

\section{BASES:}

The separation distance of 30 feet is based on engineering judgement after considering the type of the initiating events that could damage both the primary and secondary confinement boundaries. These events are earthquake, high winds, lightening, construction activities, vehicle impact, and dropped heavy loads. In addition to damaging the termination control point, the initiator also must damage both the primary and secondary confinements. The earthquake and high wind initiators have 
a wide affected area, but it is some specific object that needs to damage the confinement and control points. Lightening has a very localized affected area. Construction activities, vehicle impacts, and dropped heavy loads have an affected area that is a general line. This could damage two of the control points, but the third control point would remain available. It is not likely that the affected area would be $30 \mathrm{ft}$ wide. 


\title{
DISTRIBUTION
}

\author{
1. L. Holder \\ 2. R. S. McKeehan \\ 3. P. T. Owen \\ 4. L. B. Raulston \\ 5. S. D. Van Hoesen \\ 6. Central Research Library \\ 7. File-EMEF DMC-RC
}

